\title{
Effects of Wastewater from Oil Exploration on Soil Mesofauna
}

\author{
Raimundo N. C. Ferreira ${ }^{1}$ - Olmar B. Weber ${ }^{2} \cdot$ Maria E. F. Correia $^{3}$ • \\ Eloísa S. Benazzi-Ikeda $^{4} \cdot$ Rafael N. Scoriza $^{3} \cdot$ Antonio L. M. Mesquita $^{2}$
}

Received: 28 March 2015/ Accepted: 1 October 2015/Published online: 8 October 2015

(C) Springer Science+Business Media New York 2015

\begin{abstract}
Wastewater from oil exploration may contain substances that can alter the diversity of soil organisms. This study evaluated whether produced water treated by filtration or reverse osmosis and glutaraldehyde from reverse osmosis treatments negatively affected the mesofauna in an irrigated area. In the field, irrigation with produced water treated by reverse osmosis and filtration influenced Hymenoptera and Cosmochthonius sp., while Entomobryomorpha springtails were affected only by the reverse osmosis water. In the ecotoxicological tests, reproduction in the springtail Folsomia candida was inhibited by the reverse osmosis treatment, while reproduction in the earthworm Enchytraeus crypticus was affected by both water treatments. Although glutaraldehyde did not affect the survival of $F$. candida, the reproduction was inhibited $($ EC50 $=44.4 \mathrm{mg} / \mathrm{L})$. No adverse effect of glutaraldehyde was observed on reproduction or survival of E. crypticus. These results indicate that produced water, when used in irrigated agriculture, may affect soil functional mesofauna.
\end{abstract}

Raimundo N. C. Ferreira

nonatocferreira@gmail.com

1 Programa de Pós-Graduação em Ecologia e Recursos Naturais, Universidade Federal do Ceará, Fortaleza, CE 60455-760, Brazil

2 Centro Nacional de Pesquisa de Agroindústria Tropical, Empresa Brasileira de Pesquisa Agropecuária - EMBRAPA, Fortaleza, CE 600511-110, Brazil

3 Centro Nacional de Pesquisa de Agrobiologia, Empresa Brasileira de Pesquisa Agropecuária - EMBRAPA, Seropédica, RJ 23891-000, Brazil

4 Programa de Pós-Graduação em Ciência, Tecnologia e Inovação em Agropecuária, Universidade Federal Rural do Rio de Janeiro, Seropédica, RJ 23851-970, Brazil
Keywords Water reuse $\cdot$ Soil fauna $\cdot$ Toxicology · Glutaraldehyde

Treated water from petroleum exploration (produced water) is unfit for human consumption, but can be used for irrigation (Johnston et al. 2008). In arid and semi-arid regions with scarce water sources, it is important to reuse water (Travis et al. 2012). To be usable in crop irrigation, produced water must pass through treatment processes that remove salts, metals, and other components (Murray-Gulde et al. 2003; Melo et al. 2010).

Simple filtration of the produced water is not effective in desalting, causing salinization of the soil (Al-Haddabi and Ahmed 2007). Soil salinity can negatively affect the mesofauna (Elkins and Whitford 1984) and also change the microorganism community (Ibekwe et al. 2010), which is important as a food resource for soil fauna (de Ruiter et al. 1994). Other water treatment processes, such as reverse osmosis and ultrafiltration, are efficient in removing salts and metals. However, in these treatments, glutaraldehyde is used to prevent the formation of a biofilm on the reverse osmosis membrane. This prolongs its service life (Melo et al. 2010), but results in reduced microorganism activity in soil when this water is used in irrigation (Lopes et al. 2014).

Any negative impact on soil communities and trophic webs reduces the benefits of these organisms to the soil (Brussaard et al. 2007; Barrios 2007). In such cases, mesofauna taxa, such as nematodes, mites, worms, isopods, enchytraeids, and springtails, can serve as biomarkers of pollution (Cortet et al. 1999). Because of the importance of these animals in the nutrient cycling processes and their role in the maintenance of the physical and chemical quality of soil (Dindal 1990), the impacts on communities and populations of soil organisms should be taken into 
consideration when using produced water for irrigation. Because glutaraldehyde is used in disinfecting hospitals, effects have been evaluated only on aquatic organisms such as mollusks (SINTEF 1991), algae (Sano et al. 2005), fishes (Pereira et al. 2014), worms, and crustaceans (Sano et al. 2003, 2004, 2005; Boillot and Perrodin 2008). However, the direct and indirect effects of glutaraldehyde on soil mesofauna remain unknown. Thus, we hypothesized that the mesofauna will be affected by saline produced water or the glutaraldehyde used in reverse osmosis treatments.

The aim of this study was to evaluate whether irrigation with treated produced water affected soil mesofauna taxa in an agricultural area as compared with groundwater irrigation. We investigated the effect of irrigation on higherlevel taxa that are commonly used in environmental monitoring, and on oribatid mite species. This study also evaluated whether the soils under the irrigation treatments or exposed to glutaraldehyde had a potential ecotoxicological effect on the mesofauna species Folsomia candida (Collembola) and Enchytraeus crypticus (Oligochaeta).

\section{Materials and Methods}

The study was conducted in fields irrigated with different types of water or non-irrigated land cultivated with ornamental pineapple plants (Ananas comosus var. erectifolius (L.B. Smith) Coppens \& Leal) on the Belém farm (FZB) of Petrobras, located in the municipality of Aracati, State of Ceará (Brazil) $\left(44^{\circ} 44^{\prime} 4.23^{\prime \prime} \mathrm{S}, 37^{\circ} 32^{\prime} 23.56^{\prime} \mathrm{W}\right)$. The soil of the area was classified as Haplic Arenosol with the following size fractions $(\mathrm{g} / \mathrm{kg})$ : 978 sand, 27.4 silt, and 26.6 clay. In this area, air temperature ranges from 26 to $28^{\circ} \mathrm{C}$, annual rainfall is up to $800 \mathrm{~mm}$, and it has a hot, semi-arid climate according to the Köppen classification.

The sampling units comprised nine plots of $400 \mathrm{~m}^{2}$ that were arranged in a completely randomized design with three replications for each irrigation treatment and distributed in an area of $19,200 \mathrm{~m}^{2}$. The three treatments included: (1) control treatment with groundwater (Groundwater); (2) produced water filtered in sand filters and then treated by reverse osmosis (APO); and (3) produced water that was only filtered (APF). The concentration of glutaraldehyde present in the water from the reverse osmosis treatment was approximately $0.198 \mathrm{mg} / \mathrm{L}$ (Melo et al. 2010). Each treatment modified the chemical characteristics of the soil (Table 1).

The plots were planted with ornamental pineapples in February 2013, with a 1-m spacing between rows and a $0.3-\mathrm{m}$ spacing between plants in each row. These areas were previously equipped with a drip irrigation system. The total amount of water applied during the year was
$803 \mathrm{~L} / \mathrm{m}^{2}$ for the Groundwater and APO treatments, and $843 \mathrm{~L} / \mathrm{m}^{2}$ in the APF treatment. Irrigation was applied daily (approximately $2.3 \mathrm{~L} / \mathrm{m}^{2}$ ), and water depths were calculated based on the estimated crop evapotranspiration and drainage losses measured with small-scale lysimeter (diameter $=0.4 \mathrm{~m}$ and depth $=0.7 \mathrm{~m}$ ). All plots received the same amount of fertilizers, Ethrel flowering inductor (2-chloroethylphosphonic acid, $24 \% \mathrm{~m} / \mathrm{v}$ ), and other common practices in pineapple cultivation (Souza and Reinhardt 2009).

The mesofauna was sampled 12 months after the start of irrigation with the three water treatments. For sampling, three undisturbed sub-samples of soil were collected in each plot using cylindrical PVC tubes $(10 \mathrm{~cm}$ high and $10 \mathrm{~cm}$ diameter). After collection, the arthropods were extracted using a Berlese-Tullgren funnel. Arthropod mesofauna were counted and identified to order or suborder, and holometabolous insects were divided into adults and larvae. The oribatid mites were identified to the species level.

In controlled laboratory conditions at Embrapa Tropical Agroindustry (Fortaleza, Ceará, Brazil), we conducted two ecotoxicological tests using Folsomia candida (ISO 11267 1999) and Enchytraeus crypticus (ISO 16387 2004) obtained from the Soil Fauna Laboratory of Embrapa Agrobiology in Seropédica (RJ, Brazil). In the first assay, reproduction of these two species was evaluated in soil samples collected from the surface layer $(0-0.1 \mathrm{~m})$ of field plots (Groundwater, APO, and APF), after 1 year of irrigation in ornamental pineapple cultivation at FZB. In the second assay, we tested the reproduction of $F$. candida and E. crypticus on a non-irrigated soil sample collected from the pineapple field at FZB that received varying glutaraldehyde dosages in the laboratory (from 0.02 to $1000 \mathrm{mg} / \mathrm{L}$ ). The concentration of glutaraldehyde in produced water treated by reverse osmosis used in this study was $0.198 \mathrm{mg} / \mathrm{L}$, which represented the daily normal exposure of soil mesofauna. Thus, the exposures represented concentrations that were both less than and greater than the normal exposure of $0.198 \mathrm{mg} / \mathrm{L}$.

For each of these two trials, we used four replicates, each with ten specimens kept in a plastic pot (diameter $4 \mathrm{~cm}$ and $7 \mathrm{~cm}$ high) containing $30 \mathrm{~g}$ of natural non-irrigated soils from the FZB. The concentrations of glutaraldehyde $(0.02$, $0.05,0.2,0.4,0.79,10,100$, and $1000 \mathrm{mg} / \mathrm{L}$ ) were prepared in deionized tap water and the soil was watered to $60 \%$ of its field capacity with each glutaraldehyde concentration. Approximately $2 \mathrm{mg}$ of lyophilized yeast was provided as food for springtails and $4 \mathrm{mg}$ of autoclaved oatmeal for the enchytraeids on the first and 14th days of the experiment. The temperature was $20 \pm 1{ }^{\circ} \mathrm{C}$, and the $\mathrm{pH}$, electrical conductivity, and moisture were evaluated at the beginning and end of the tests according to the protocol validation criteria for the two species. 
Table 1 Soil analysis data from plots irrigated with the three types of water used in this study before and after 1 year of irrigation

\begin{tabular}{|c|c|c|c|c|c|c|}
\hline \multirow[t]{2}{*}{ Soil analysis } & \multicolumn{2}{|c|}{ Groundwater } & \multicolumn{2}{|l|}{ APO } & \multicolumn{2}{|l|}{ APF } \\
\hline & Before & After & Before & After & Before & After \\
\hline Electrical conductivity $\left(\mathrm{dS} / \mathrm{m}^{2}\right)$ & 0.57 & 1.97 & 0.69 & 1.87 & 1.39 & 2.85 \\
\hline $\mathrm{pH}$ (in water $1: 2.5$ ) & 8.49 & 8.17 & 8.08 & 6.63 & 8.59 & 8.07 \\
\hline $\mathrm{Ca}(\mathrm{mg} / \mathrm{kg})$ & 10.4 & 16.7 & 14.5 & 18.2 & 11.1 & 15.9 \\
\hline $\mathrm{Mg}(\mathrm{mg} / \mathrm{kg})$ & 1.98 & 10.4 & 2.31 & 10.2 & 2.69 & 9.39 \\
\hline $\mathrm{K}(\mathrm{mg} / \mathrm{kg})$ & 0.55 & 1.74 & 0.64 & 1.66 & 0.54 & 2.06 \\
\hline $\mathrm{Na}(\mathrm{mg} / \mathrm{kg})$ & 0.12 & 7.45 & 0.16 & 4.69 & 0.15 & 11.1 \\
\hline $\mathrm{Cu}(\mathrm{mg} / \mathrm{kg})$ & 0.03 & 1.13 & 0.03 & 0.39 & 0.03 & 0.16 \\
\hline $\mathrm{Fe}(\mathrm{mg} / \mathrm{kg})$ & 7.13 & 47.1 & 6.02 & 37.2 & 8.22 & 35.7 \\
\hline $\mathrm{Mn}(\mathrm{mg} / \mathrm{kg})$ & 14.8 & 31.2 & 11.8 & 30.2 & 21.56 & 20.9 \\
\hline $\mathrm{Zn}(\mathrm{mg} / \mathrm{kg})$ & 0.83 & 5.86 & 0.91 & 3.59 & 0.74 & 5.96 \\
\hline $\mathrm{P}(\mathrm{mg} / \mathrm{kg})$ & 201 & 127 & 286 & 149 & 242 & 141 \\
\hline $\mathrm{PAHs}^{\mathrm{a}}$ & $\mathrm{ND}^{\mathrm{c}}$ & ND & ND & ND & ND & ND \\
\hline BTEX $^{b}$ & $\mathrm{ND}^{\mathrm{d}}$ & ND & ND & ND & ND & ND \\
\hline
\end{tabular}

${ }^{\mathrm{a}} P A H s$ polycyclic aromatic hydrocarbon, ${ }^{\mathrm{b}} B T E X$ benzene, toluene, ethylbenzene, and xylenes, ${ }^{\mathrm{c}} N D$ none detected above the analytical detection limit of $2.7 \mathrm{mg} / \mathrm{kg},{ }^{\mathrm{d}} N D$ none detected above the analytical detection limit of $2 \mathrm{mg} / \mathrm{kg}$
To evaluate whether an irrigation treatment affected individual mesofauna taxa, the analysis of indicator species (IndVal) proposed by Dufrêne and Legendre (1997) was used. IndVal values range from 0 to 1 . Values closer to 1 indicate stronger associations of a species with a specific treatment. Significance values associated with IndVal were calculated by randomization tests. We did not include taxa with a frequency $\leq 10 \%$ because that is a precondition for the IndVal analysis to be valid. Dominance ranking diagrams were constructed to evaluate changes in the patterns of dominance among the irrigation treatments. In the diagrams, the dominance gradient was represented by the $\mathrm{X}$-axis and calculated from the relative abundance (on the Y-axis) of each taxon collected in the irrigation treatments. We considered the groundwater to be the control treatment.

In ecotoxicological tests, the reproduction and survival of $F$. candida and E. crypticus were measured and the effect of glutaraldehyde evaluated using generalized linear models (GLM) modeled by the Poisson distribution. Effective concentration values (EC50) were calculated for organisms that had a significant decrease in their reproduction rates with glutaraldehyde by fitting the data to a logistic regression $(\log )$. In all analyses, we used the statistical program R (R Development Core Team 2014).

\section{Results and Discussion}

We identified 18 taxonomic groups of arthropods in the three irrigation treatments evaluated. Astigmata, Mesostigmata, and Oribatida mites were the most common organisms collected in the soil under both water-impacted treatments; however, Prostigmata mites occurred in small numbers. In this study, the greatest soil salinity disturbance occurred in the APF treatment. Astigmata are mites that rapidly colonize disturbed areas because of their rapid development and high reproductive rate (Philips 1990; Norton 1994). Predatory mites, such as Mesostigmata, have good dispersion rates and usually have a rapid lifecycle (Koehler 1999); therefore, they can colonize many impacted ecosystems (Lindquist et al. 2009).

Five species of oribatid mites were found in all treatments. Among these species, only Cosmochthonius sp., commonly found in more arid environments, was significantly associated with one of the treatments, in this case, the Groundwater treatment (Table 2). Species of the family Cosmochthoniidae are relatively abundant in environments with more open vegetation in arid and semi-arid climates (Silva et al. 1989; Penttinen and Gordeeva 2010), savannas (Santos et al. 2008; Ferreira et al. 2012), and agroecosystems (Osler and Murphy 2005). However, their abundance is higher in less contaminated areas (Osler and Murphy 2005).

A few organisms were related to one of the irrigation treatments, including the order Hymenoptera (excluding Formicidae), which occurred in the less impacted treatment (Groundwater). Some species of Hymenoptera that nest in the soil are sensitive to certain soil disturbances, such as physical impacts like trampling by animals (Bonte 2005), while others may be less abundant in soils with higher heavy metal concentrations (Nahmani and Rossi 2003). However, because some of the organisms were identified only to higher taxonomic levels which obscures any habitat partitioning that may be occurring at the species level (Franklin et al. 
Table 2 IndVal values for mesofauna of each group collected in the area cultivated with ornamental pineapple (Ananas comosus var. erectifolius) and submitted to three irrigation treatments

\begin{tabular}{lllll}
\hline Treatment & Taxa & IndVal & $p$ & ${ }^{\mathrm{a}}$ Frequency (\%) \\
\hline Groundwater & Hymenoptera & $\mathbf{0 . 5 3}$ & $\mathbf{0 . 0 1}$ & 29.63 \\
Groundwater & Formicidae & 0.17 & 0.62 & 18.52 \\
Groundwater & Cosmochthonius sp. & $\mathbf{0 . 4 4}$ & $\mathbf{0 . 0 2}$ & 14.81 \\
Groundwater & Lamellobates molecula & 0.20 & 0.53 & 11.11 \\
APO & Coleoptera (larvae) & 0.30 & 0.33 & 29.63 \\
APO & Prostigmata & 0.29 & 0.23 & 33.33 \\
APO & Coleoptera (adult) & 0.22 & 0.99 & 62.96 \\
APO & Psocoptera & 0.15 & 0.87 & 22.22 \\
APO & Galumna sp. & 0.28 & 0.15 & 14.81 \\
APO & Afronothrus sp. & 0.23 & 0.56 & 29.63 \\
APO & Archegozetes longisetosus & 0.10 & 1.00 & 11.11 \\
APF & Entomobryomorpha & $\mathbf{0 . 5 6}$ & $\mathbf{0 . 0 5}$ & 66.67 \\
APF & Mesostigmata & 0.45 & 0.18 & 81.48 \\
APF & Astigmata & 0.22 & 0.91 & 51.85 \\
\hline
\end{tabular}

${ }^{a}$ Calculated as the percentage of samples where each taxon occurs

Numbers in bold represent significant IndVal values $(p \leq 0.05)$
2005), little can be explained about the effects of salinity in APF or the presence of glutaraldehyde in APO on these organisms. In the case of Collembola in the order Entomobryomorpha, which were affected by the APO, the glutaraldehyde used in this treatment may have affected their populations because they have greater sensitivity to various types of contaminants (Cortet et al. 1999).

Although most taxa were not significantly different among the irrigation treatments, we observed changes in dominance patterns. In the Groundwater treatment, the four dominant groups were in the following order: Oribatida ( $L$. molecula), Entomobryomorpha, Astigmata, and Mesostigmata. The species Cosmochthonius sp. and the order Hymenoptera (excluding Formicidae), which were significantly associated with the Groundwater treatment (Table 2), were the sixth and the ninth most dominant groups, respectively (Fig. 1).

In the APO treatment, the pattern of dominance was the most different from the others. Astigmata, Oribatida (A. longisetosus), Mesostigmata, and Entomobryomorpha were dominant, although A. longisetosus was among the less dominant in the Groundwater treatment and did not occur in the APF treatment (Fig. 1). Collembola of the order Entomobryomorpha were dominant in APF and were significantly associated with this treatment (Table 2). The Entomobryomorpha were the organisms were that most changed in terms of dominance patterns, notably in APO.

Changes in dominance observed among the treatments can occur due to variations in biotic or abiotic conditions (Rae et al. 2006; Gilbert et al. 2009) or in the availability of resources. There were changes in habitat promoted by irrigation with APF (which is rich in salts) or APO (with the presence of biocides) in relation to the Groundwater

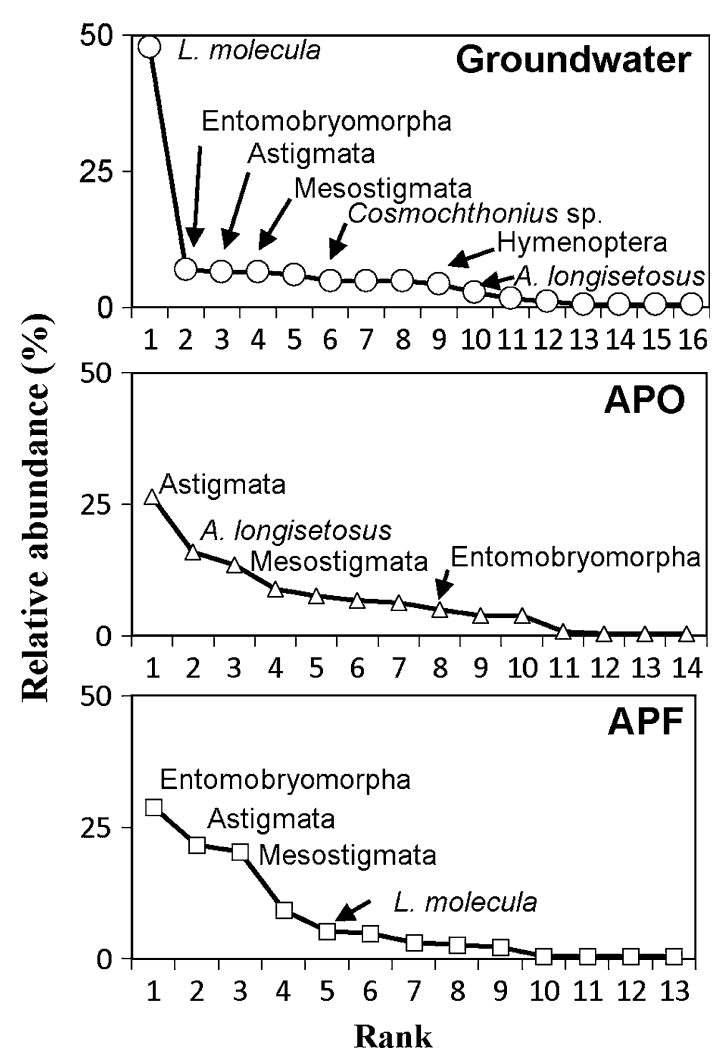

Fig. 1 Dominance rank diagram of taxa collected in ornamental pineapple cultivation (Ananas comosus var. erectifolius) submitted to three irrigation treatments. Only the most abundant organisms are highlighted

treatment. This indicates that the irrigation treatments may have interfered with reproduction in some organisms, thereby changing the dominance patterns among taxa. 
The ecotoxicological tests demonstrated that produced water had some effect on the reproduction of $F$. candida and E. crypticus, but not on their survival. In fact, the survival of an Enchytraeidae species and F. candida were not affected by high salinity (Owojori et al. 2009). Despite the higher salt content in soil irrigated with APF than that in the other treatments, the reproduction of $F$. candida was significantly lower only in soil irrigated with APO ( $p<0.01)$, probably because of glutaraldehyde. Reproduction in the APF treatment was similar to that in the Groundwater treatment ( $p=0.38$ ) (Fig. 2).

In the case of E. crypticus, both APO $(p=0.02)$ and APF negatively affected the reproduction $(p=0.02)$ of these organisms (Fig. 2). Terrestrial annelids like $E$. crypticus have more sensitive teguments and have direct contact with the soil solution (Laverack 1963). The long period of presence of glutaraldehyde in water may have concentrated that contaminant in the soil, and its effect, combined with other characteristics of APO, altered the physiology of these soil organisms. APF increased the salt content of the soil. Ions such as sodium and chlorine, can also adversely affect the reproduction of annelids, most of which are not tolerant to higher salt concentrations in the soil solution (Jänsch et al. 2005).

Mortality in the control, juvenile production, and the coefficient of variation occurred within the range established by the protocols used. No significant adverse effects upon survival were observed in natural soil concentrations of up to $1000 \mathrm{mg} / \mathrm{L}$ of glutaraldehyde on $F$. candida. However, there was a negative impact on the reproduction during exposure to $100(p<0.01)$ and $1000 \mathrm{mg} / \mathrm{L}$ $(p<0.01)$ (Fig. 3). The EC50 value for reproduction was $44.4 \mathrm{mg}$ glutaraldehyde per liter of water in the soil.

Because it is a more common contaminant in wastewater (especially from hospitals) and in aquaculture, the ecotoxicological effects of glutaraldehyde have been evaluated for the survival of aquatic organisms (Leung 2001; Pereira et al. 2014). In the present study, the EC50 value of glutaraldehyde at $44.4 \mathrm{mg} / \mathrm{L}$ for $F$. candida is higher than that found for effects upon reproduction in other arthropods. Reproduction tests showed a low concentration effect in crustaceans ranging from $4.25 \mathrm{mg} / \mathrm{L}$ for Daphnia magna (Leung 2001) to $4.90 \mathrm{mg} / \mathrm{L}$ (Sano et al. 2005) for Ceriodaphnia dubia. Thus, more glutaraldehyde in the soil was necessary to reduce the reproduction rate. There was no effect of concentrations up to $1000 \mathrm{mg} / \mathrm{L}$ of glutaraldehyde on the survival of $F$. candida in our study. The survival of invertebrates in glutaraldehyde was better evaluated by other studies in aquatic organisms, and the only arthropods evaluated were crustaceans. In aquatic arthropod tests, the EC50 of glutaraldehyde ranged from $0.11 \mathrm{mg} / \mathrm{L}$ for Copepoda to $582 \mathrm{mg} / \mathrm{L}$ for Amphipoda (see Pereira et al. 2014).

The reproduction and survival of E. crypticus was not affected at a concentration of $1000 \mathrm{mg} / \mathrm{L}$ in the soil. Ecotoxicological tests with glutaraldehyde have been reported only for aquatic annelids, and these studies found that EC50 values were lower than $1000 \mathrm{mg} / \mathrm{L}$. In survival tests with the aquatic oligochaete Lumbriculus variegatus, EC50 values were 11.1 (Sano et al. 2003), and 6.3-16 mg/L (Sano et al. 2004). In terrestrial environments, the organisms have less contact with water and glutaraldehyde is more easily degraded in soil (Leung 2001), thus a greater concentration may be required to affect the reproduction of the organisms evaluated.

Irrigation with produced water affected mesofauna identified at high taxonomic categories and oribatid mite species. The dominance relations among taxa were changed in soils irrigated with produced water from different treatment processes. Some mesofauna taxa exhibit a shift in the order of dominance when exposed to soils under irrigation with produced water, regardless of how the water was treated. Although the high doses of glutaraldehyde used in the treatment of reverse osmosis did not affect
Fig. 2 Reproduction of $F$. candida and E. crypticus on soil collected from three irrigation treatments. Identical letters indicate that treatments were not significantly different $(p>0.05)$
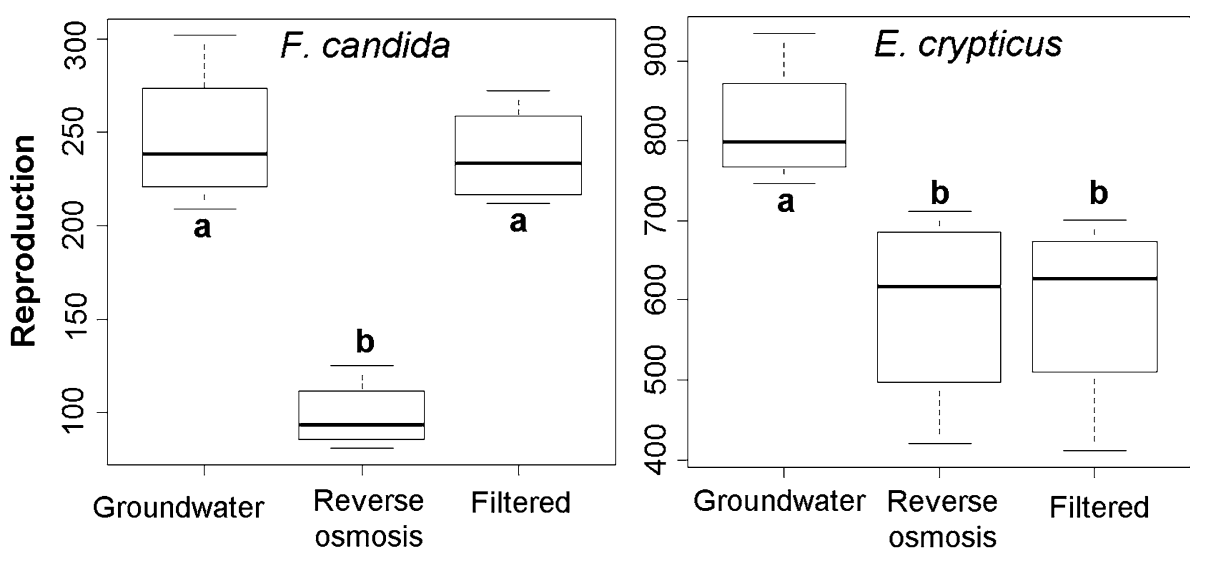

\section{Treatments}




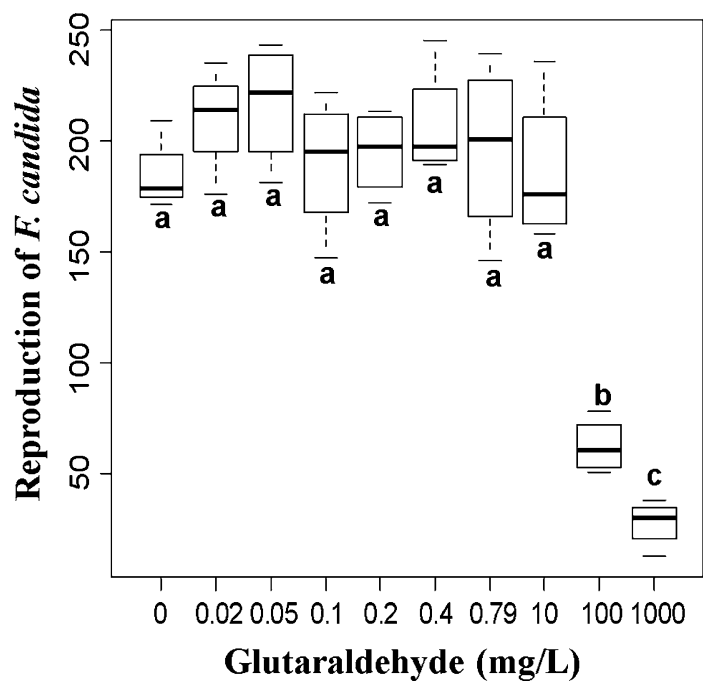

Fig. 3 Reproduction of $F$. candida in natural soil watered at $60 \%$ of field capacity with different aqueous concentrations of glutaraldehyde. Identical letters indicate that treatments were not significantly different $(p>0.05)$

survival of the mesofauna, reproduction was clearly affected in both $F$. candida and E. crypticus. Further studies are needed to ascertain the causes of the observed mesofaunal dominance pattern shifts in soils irrigated with oil exploration wastewater.

Acknowledgments This study is part of a project on the reuse of produced water for irrigation. The authors thank Petrobras for financial support, Capes for a doctoral student scholarship, and Embrapa Agrobiology and Embrapa Tropical Agroindustry for logistics and laboratory facilities.

\section{References}

Al-Haddabi M, Ahmed M (2007) Land disposal of treated saline oil production water: impacts on soil properties. Desalination 212:54-61. doi:10.1016/j.desal.2006.09.019

Barrios E (2007) Soil biota, ecosystem services and land productivity. Ecol Econ 64:269-285. doi:10.1016/j.ecolecon.2007.03.004

Boillot C, Perrodin Y (2008) Joint-action ecotoxicity of binary mixtures of glutaraldehyde and surfactants used in hospitals: use of the toxicity index model and isobologram representation. Ecotoxicol Environ Saf 71:252-259. doi:10.1016/j.ecoenv.2007. 08.010

Bonte D (2005) Anthropogenic induced changes in nesting densities of the dune-specialised digger wasp Bembix rostrata (Hymenoptera: Sphecidae). Eur J Entomol 102:809-812. doi:10. 14411/eje.2005.114

Brussaard L, Deruiter P, Brown GG, de Ruiter PC (2007) Soil biodiversity for agricultural sustainability. Agric Ecosyst Environ 121:233-244. doi:10.1016/j.agee.2006.12.013

Cortet J, Vauflery AG-D, Poinsot-Balaguer N et al (1999) The use of invertebrate soil fauna in monitoring pollutant effects. Eur J Soil Biol 35:115-134. doi:10.1016/S1164-5563(00)00116-3

Development Core Team R (2014) R: a language and environment for statistical computing. R Foundation for Statistical Computing, Vienna de Ruiter PC, Neutel AM, Moore JC (1994) Modelling food webs and nutrient cycling in agro-ecosystems. Trends Ecol Evol 9:378-383. doi:10.1016/0169-5347(94)90059-0

Dindal DL (1990) Soil biology guide. Wiley, New York

Dufrêne M, Legendre P (1997) Species assemblages and indicator species: the need for a flexible asymmetrical approach. Ecol Monogr 67:345-366. doi:10.1890/0012-9615(1997)067[0345: SAAIST]2.0.CO;2

Elkins NZ, Whitford WG (1984) The effects of high salt concentration on desert soil microarthropod density and diversity. Southwest Nat 30:239-241

Ferreira RNC, Franklin E, de Souza JLP, de Moraes J (2012) Soil oribatid mite (Acari: Oribatida) diversity and composition in semi-deciduous forest fragments in eastern Amazonia and comparison with the surrounding savanna matrix. J Nat Hist 46:2131-2144. doi:10.1080/00222933.2012.707245

Franklin E, Magnusson WE, Luizão FJ (2005) Relative effects of biotic and abiotic factors on the composition of soil invertebrate communities in an Amazonian savanna. Appl Soil Ecol 29:259-273. doi:10.1016/j.apsoil.2004.12.004

Gilbert B, Turkington R, Srivastava DS (2009) Dominant species and diversity: linking relative abundance to controls of species establishment. Am Nat 174:850-862. doi:10.1086/647903

Ibekwe AM, Poss JA, Grattan SR et al (2010) Bacterial diversity in cucumber (Cucumis sativus) rhizosphere in response to salinity, soil pH, and boron. Soil Biol Biochem 42:567-575. doi:10.1016/ j.soilbio.2009.11.033

ISO 11267 (1999) Soil quality-inhibition of reproduction of Collembola (Folsomia candida) by soil pollutants. International Organization For Standardization, Geneva

ISO 16387 (2004) Soil quality —effects of pollutants on Enchytraeidae (Enchytraeus sp.): determination of effects on reproduction and survival. International Organization For Standardization, Geneva

Jänsch S, Römbke J, Didden W (2005) The use of enchytraeids in ecological soil classification and assessment concepts. Ecotoxicol Environ Saf 62:266-277. doi:10.1016/j.ecoenv.2004.10.025

Johnston CR, Vance GF, Ganjegunte GK (2008) Irrigation with coalbed natural gas co-produced water. Agric Water Manag 95:1243-1252. doi:10.1016/j.agwat.2008.04.015

Koehler HH (1999) Predatory mites (Gamasina, Mesostigmata). Agric Ecosyst Environ 74:395-410. doi:10.1016/S01678809(99)00045-6

Laverack M (1963) The physiology of earthworms. Pergamon Press, Oxford

Leung HW (2001) Ecotoxicology of glutaraldehyde: review of environmental fate and effects studies. Ecotoxicol Environ Saf 49:26-39. doi:10.1006/eesa.2000.2031

Lindquist EE, Krantz GW, Walter DE (2009) Order Mesostigmata. In: Krantz GW, Walter DE (eds) A manual of acarology, 3rd edn. Texas Tech University Press, Lubbock, pp 124-232

Lopes EDOR, Weber OB, Crisóstomo LA, de Mattos EPNB (2014) Short-term effects of produced water on microbial activity in semiarid soil. Int J Curr Microbiol Appl Sci 3:295-403

Melo M, Schluter H, Ferreira J et al (2010) Advanced performance evaluation of a reverse osmosis treatment for oilfield produced water aiming reuse. Desalination 250:1016-1018. doi:10.1016/j. desal.2009.09.095

Murray-Gulde C, Heatley JE, Karanfil T et al (2003) Performance of a hybrid reverse osmosis-constructed wetland treatment system for brackish oil field produced water. Water Res 37:705-713. doi:10.1016/S0043-1354(02)00353-6

Nahmani J, Rossi J-P (2003) Soil macroinvertebrates as indicators of pollution by heavy metals. C R Biol 326:295-303. doi:10.1016/ S1631-0691(03)00070-2

Norton R (1994) Evolutionary aspects of oribatid mite life histories and consequences for the origin of the Astigmata. In: Houck M 
(ed) Mites: ecological and evolutionary analyses of life-history patterns. Chapman \& Hall, New York, pp 99-135

Osler GHR, Murphy DV (2005) Oribatid mite species richness and soil organic matter fractions in agricultural and native vegetation soils in Western Australia. Appl Soil Ecol 29:93-98. doi:10. 1016/j.apsoil.2004.09.002

Owojori OJ, Reinecke AJ et al (2009) Comparative study of the effects of salinity on life-cycle parameters of four soil-dwelling species (Folsomia candida, Enchytraeus doerjesi, Eisenia fetida and Aporrectodea caliginosa). Pedobi 52:351-360. doi:10.1016/ j.pedobi.2008.12.002

Penttinen R, Gordeeva E (2010) Distribution of Cosmochthonius species (Oribatida: Cosmochthoniidae) in the eastern part of the Mediterranean, Ukraine and Tajikistan. In: Sabelis MW, Bruin J (eds) Trends acarology, vol 27. Springer, Netherlands, pp 171-174

Pereira SPP, Oliveira R, Coelho S et al (2014) From sub cellular to community level: toxicity of glutaraldehyde to several aquatic organisms. Sci Total Environ 470-471:147-158. doi:10.1016/j. scitotenv.2013.09.054

Philips JR (1990) Acarina: Astigmata (Acaridida). In: Dindal DL (ed) Soil biology guide. Wiley, New York, pp 757-778

Rae DA, Armbruster WS, Edwards ME, Svengård-Barre M (2006) Influence of microclimate and species interactions on the composition of plant and invertebrate communities in alpine northern Norway. Acta Oecol 29:266-282. doi:10.1016/j.actao. 2005.11.007

Sano LL, Moll RA, Krueger AM, Landrum PF (2003) Assessing the potential efficacy of glutaraldehyde for biocide treatment of unballasted transoceanic vessels. J Great Lakes Res 29:545-557. doi:10.1016/S0380-1330(03)70458-4
Sano LL, Mapili MA, Krueger A et al (2004) Comparative efficacy of potential chemical disinfectants for treating unballasted vessels. J Great Lakes Res 30:201-216. doi:10.1016/S03801330(04)70340-8

Sano LL, Krueger AM, Landrum PF (2005) Chronic toxicity of glutaraldehyde: differential sensitivity of three freshwater organisms. Aquat Toxicol 71:283-296. doi:10.1016/j.aquatox.2004. 12.001

Santos EMR, Franklin E, Magnusson WE (2008) Cost-efficiency of subsampling protocols to evaluate oribatid-mite communities in an Amazonian savanna. Biotropica 40:728-735. doi:10.1111/j. 1744-7429.2008.00425.x

Silva S, Whitford WG, Jarrell WM, Virginia RA (1989) The microarthropod fauna associated with a deep rooted legume, Prosopis glandulosa, in the Chihuahuan Desert. Biol Fertil Soils 7:330-335. doi:10.1007/BF00257828

SINTEF (1991) Ucarcide 150. Acute toxicity to mussel (Mytilus edulis), marine phytoplankton (Skeletonema costatum) - inhibition of growth rate, acorn barnacle (Balanus improvisus) repressing of the settlement and metamorphosis. Oslo

Souza LFS, Reinhardt DH (2009) Pineapple. In: Crisóstomo LA, Naumov A (eds) Fertilizing for high yield and quality tropical fruits of Brazil. International Potash Institute, Horgen, pp 179-201. ISBN 978-3-9523243-1-8

Travis MJ, Weisbrod N, Gross A (2012) Decentralized wetland-based treatment of oil-rich farm wastewater for reuse in an arid environment. Ecol Eng 39:81-89. doi:10.1016/j.ecoleng.2011. 11.008 